\title{
Pengembangan Kreatifitas Anak Usia Dini Melalui Bentuk Geometri di Era Digital
}

\author{
Heri Hidayat ${ }^{1}$, Dela Delviana ${ }^{2}$, Dinar Farida Fauziah ${ }^{3}$, Maudina Yuniar ${ }^{4}$ \\ Pendidikan Islam Anak Usia Dini, Universitas Islam Negeri Sunan Gunung Djati Bandung \\ DOI: 10.31004/aulad.v4i1.85
}

Corresponding author: [herihidayat@uinsgd.ac.id]

\begin{tabular}{ll}
\hline Article Info & Abstrak \\
\hline Kata kunci: & Penelitian ini bertujuan untuk melihat perkembangan kreativitas anak usia dini \\
Geometri; & melalui bentuk geometri di era digital, penulis menemukan bahwa perkembangan \\
Kreativitas; & kreativitas tersebut dapat dilihat dari penggunaan media permainan seperti \\
Mengembangkan & tangram atau kepingan geometri. Metode penelitian yang digunakan adalah kajian \\
Permainan & pustaka atau studi kepustakaan yaitu berisi teori teori yang relevan dengan \\
Tangram & masalah-masalah penelitian. Hasil penelitian ini didukung dengan penelitian yang \\
& dilakukan Putri Rahmi, dkk di TKN Pembina Lawe Alas, menyatakan bahwa \\
& bermain tangram dapat meningkatkan kreativitas anak dalam mengenal bentuk- \\
& bentukgeometri. Melalui 3 tahap pengujian, anak mengalami peningkatan disetiap \\
& tahapannya, sehingga secara keseluruhan terjadi perkembangan kreativitas anak \\
& mencapai 70\% melalui permainan tangram. Selain itu penelitian yang dilakukan \\
& pada Kelompok B TK IT Permata Bunda Mranggen Demak, Kelompok B di TK Aba \\
& Jemawan IV Jatinom dan Kelompok Belajar Bina Insan Mandiri Kecamatan \\
& Cimalaka Kabupaten Sumedang yang menyatakan bahwa permainan tersebut \\
& memberi pengaruh yang positif pada anak. Sehingga pengalaman menggunakan \\
& Tangram membantu anak-anak mengembangkan sikap positif terhadap geometri, \\
& mengembangkan keterampilan identifikasi dan klasifikasi mereka, dan \\
& menumbuhkan pemahaman tentang konsep dan hubungan geometris dasar.
\end{tabular}

Abstract

Keywords:

Geometry;

Creativity;

Develop

Game

Tangram

This study aims to see the development of early childhood creativity through geometric shapes in the digital era. The authors found that the development of creativity can be seen from the use of game media such as tangram or geometric pieces. The research method used is literature review or literature study, which contains theoretical theories that are relevant to research problems. The results of this study are supported by research conducted by Putri Rahmi, et al at TKN Pembina Lawe Alas, which states that playing tangram can increase children's creativity in recognizing geometric shapes. Through 3 stages of testing, children experience an increase in each stage, so that overall the development of children's creativity reaches $70 \%$ through tangram games. In addition, research conducted at Group B TK IT Permata Bunda Mranggen Demak, Group B at TK Aba Jemawan IV Jatinom and the Bina Insan Mandiri Study Group, Cimalaka District, Sumedang Regency stated that the game had a positive influence on children. So the experience of using Tangram helps children develop positive attitudes to geometry, develop their identification and classification skills, and foster an understanding of basic geometric concepts and relationships. 


\section{PENDAHULUAN}

Pendidikan mengemban tugas untuk dapat mengembangkan potensi kreatif yang dimiliki setiap anak. Mereka perlu mendapat bimbingan yang tepat, sehingga memungkinkan mereka dapat mengembangkan potensi dan kemampuan secara optimal. Pada akhirnya kemampuan tersebut dapat berguna bagi dirinya, keluarga, bangsa dan negara.

Undang-Undang No. 20 tahun 2003 tentang Sistem Pendidikan Nasional Bab 1 Pasal 1 Ayat 14 yang menyatakan bahwa, Pendidikan Anak Usia Dini adalah suatu upaya pembinaan yang ditujukan kepada anak, sejak lahir sampai dengan usia enam tahun, yang dilakukan melalui pemberian rangsangan untuk membantu pertumbuhan dan perkembangan jasmani dan rohani agar anak memiliki kesiapan dan pendidikan lebih lanjut. (Erna Roostin, 2018)

Kreativitas merupakan komponen individual prilaku sosial sejak zaman dahulu, tumbuhnya kreativitas dapat dicapai melalui lingkungan keluarga dan sekolah, anak memerlukan lingkungan yang kondusif untuk dapat mengembangkan bakat (intelegensi, kreativitas, dan motivasi) dan kemampuannya secara optimal untuk dapat mewujudkan dirinya sesuai dengan kebutuhan pribadinya dan kebutuhan masyarakat .(Peny Husna Handayani, Apiek Gandamana, dan Farihah, 2017).

Mengembangkan kreativitas anak usia dini seharunya menggunakan metode yang mampu mendorong anak untuk bereksplorasi, berimajinasi, mencari serta menemukan jawaban sendiri, membuat pertanyaan, membantu memecahkan masalah, memikirkan kembali, membangun kembali dan menemukan ide-ide baru. Adapun Indikator perkembangan kreativitas anak umur 5-6 tahun berdasarkan kemendiknas (2013) yaitu:(1) anak sudah dapat memecahkan masalah secara kreatif, (2) menyajikan berbagai karya yang berhubungan dengan lingkungan (dalam bentuk gambar, bercerita, bernyanyi, dangerak tubuh), dan yang ke (3) menunjukkan karya dan aktivitas seni dengan menggunakan berbagai media. (Putri Rahmi, dkk, 2020)

Dapat disimpulkan bahwa kreativitas adalah kebutuhan di masa kini dan juga masa yang akan datang. Kreativitas sangat diperlukan untuk menjemput abad persaingan karena pengembangkan kreativitas individu dapat menghasilkan karya inovatif atau sesuatu yang baru yang dibutuhkan oleh zaman (Suroso, 2002). Menurut Degraff dan Lowrence (Suratno,2005) menyatakan bahwa kreativitas adalah suatu aktivitas yang bertujuan, menghasilkan produk yang bernilai, jasa atau ide baru. Berdasarkan definisi di atas bahwa kreativitas merupakan suatu proses mental individu yang melahirkan gagasan, ide atau produk baru yang efektif dan bernilai untuk pemecahan suatu masalah.

Penulis tertarik untuk melakukan penelitian yang berjudul "Pengembangan Kreativitas Anak Usia Dini Melalui Bentuk Geometri di Era Digital”, ini karena lebih menjelaskan bahwa melalui pembelajaran bentuk geometri ini, dapat menstimulus tingkat kreativitas anak dalam hal berimajinasi, membangun berbagai bentuk bentuk dari geometri dan lain sebagainya.

Menurut Semiawan mengemukakan bahwa kreativitas merupakan kemampuan untuk memberikan gagasan baru dan menerapkannya dalam pemecahan masalah. Menurut Degraff dan Lowrence (dalam Suratno,2005:24) menyatakan bahwa kreativitas adalah suatu aktivitas yang bertujuan, menghasilkan produk yang bernilai, jasa atau ide baru.

Berdasarkan definisi di atas dapat disimpulkan bahwa kreativitas merupakan suatu proses mental individu yang melahirkan gagasan, ide atau produk baru yang efektif dan bernilai untuk pemecahan suatu masalah.menurut Suratno, (2005: 5), mengatakan bahwa ada beberapa manfaat kreativitas untuk anak usia dini, yaitu : Kreativitas untuk memecahkan suatu masalah, Kreativitas untuk merealisasikan perwujudan dini, Kreativitas untuk memuaskan diri, dan Kreativitas untuk meningkatkan kualitas hidup.

Kreativitas adalah suatu kondisi, sikap atau keadaan yang sangat khusus sifatnya dan hampir tidak mungkin dirumuskan secara tuntas, kreativitas juga didefinisikan dalam beraneka ragam pernyataan tergantung siapa dan bagaimana menyorotinya (Ida Nursanti dan Ismatul Khasanah 2014-2015).

Bermain adalah kegiatan yang dilakukan atas dasar suatu kesenangan dan tanpa mempertimbangkan hasil akhir. Menurut Zulkifli (2006: 38) bermain adalah kesibukan yang dipilih sendiri tanpa ada unsur paksaan, tanpa didesak oleh rasa tanggung jawab, sependapat dengan hal tersebut Hurlock (Suyadi, 2010:213) menyatakan bahwa bermain adalah aktivitas-aktivitas untuk memperoleh kesenangan. Herbert Spencer menyatakan anak bermain karena mereka punya energi berlebih, energi ini mendorong mereka untuk melakukan aktivitas sehingga mereka terbebas dari perasaan tertekan, menurut Karl Groos, anak bermain karena anak perlu belajar peran-peran tertentu dalam kehidupan: peran dokter, tentara, pedagang merekajuga perlu melepaskan desakan emosi secara tepat (Ida Nursanti dan Ismatul Khasanah 2014-2015). 
Geometri merupakan salah satu cabang ilmu matematika yang sangat terkait dengan bentuk, ukuran, dan pemposisian. Menurut Juwita, dkk (2000: 266) Geometri adalah studi hubungan ruang. Pembelajaran anak usia dini termasuk pendalaman benda-benda serta hubungan-hubungannya, sekaligus pengakuan bentuk dan pola. Anak mampu mengenali, mengelompokkan, dan menyebutkan nama-nama bentuk bangun, baik bangun datar ataupun bangun ruang yang bermacam-macam ukuran dan bentuknya. Geometri adalah membangun konsep dimulai dengan mengidentifikasi bentuk-bentuk dan menyelidiki bangunan dan memisahkan gambar-gambar seperti segi empat, lingkaran, segitiga.

Bermain mencipta bidang dari kepingan geometri merupakan salah satu permainan yang diberikan oleh guru kepada anak didik dengan menggunakan berbagai potongan dari kertas yang dibentuk menjadi bentuk-bentuk geometri dengan tujuan selain untuk mengenalkan anak dengan bentuk-bentuk geometri juga bertujuan untuk mengasah kreativitas anak. Fungsi bermain mencipta bidang dari kepingan geometri sebagai sarana dalam mengembangkan kreativitas anak. (Ida Nursanti dan Ismatul Khasanah 2014-2015)

\section{METODE}

Adapun metode penelitian kajian pustaka atau studi kepustakaan yaitu berisi teori teori yang relevan dengan masalah-masalah penelitian. Studi kepustakaan adalah teknik pengumpulan data dengan mengadakan studi penelaahan terhadap buku-buku, literatur-literatur, catatan-catatan, dan laporanlaporan yang ada hubungannya dengan masalah yang dipecahkan. Pada bagian ini dilakukan pengkajian mengenai konsep dan teori yang digunakan berdasarkan literatur yang tersedia, terutama dari artikelartikel yang dipublikasikan dalam berbagai jurnal ilmiah. Kajian pustaka berfungsi untukmembangun konsep atau teori yang menjadi dasar studi dalam penelitian. (V.Wiratna Sujarweni 2014)

Kajian pustaka atau studi pustaka merupakan kegiatan yang diwajibkan dalam penelitian, khususnya penelitian akademik yang tujuan utamanya adalah mengembangkan aspek teoritis maupun aspek manfaat praktis (sukardi 2013). Sehingga dengan menggunakan metode penelitian ini penulis dapat dengan mudah menyelesaikan masalah yang hendak diteliti. Dilihat dari jenis penelitiannya, adapun jenis penelitian yang digunakan dalam penelitian ini adalah penelitian kepustakaan atau library research,yakni penelitian yang dilakukan melalui mengumpulkan data atau karya tulis ilmiah yang bertujuan dengan obyek penelitian atau pengumpulan data yang bersifat kepustakaan, atau telaah yang dilaksanakan untuk memecahkan suatu masalah yang pada dasarnya tertumpu pada penelaahan kritis dan mendalam terhadap bahan-bahan pustaka yang relevan.

\section{HASIL DAN PEMBAHASAN}

Berdasarkan studi pustaka, untuk melihat perkembangan kreativitas anak usia dini melalui bentuk geometri di era digital, penulis menemukan bahwa perkembangan kreativitas di TKN Pembinan Lawe Alas, TK IT Permata Bunda Mranggen Demak, TK ABA Jemawan IV Jatinom dan Kelompok Belajar Bina Insan Mandiri Kabupaten Sumedang, semuanay dapat dilihat dari penggunaan media permainan seperti tangram atau kepingan geometri. Permainan tersebut memberikan kesempatan anak untuk menyusun bentuk-bentuk geometri kedalam bentuk lain sesuai dengan kreativitas anak tersebut.

Tangram atau melalui tujuh bagan kebijakan dan tujuh bagan kecerdikan (Pitadjeng;2006) yang digunakan di empat lembaga tersebut diatas, peserta didik dapat mengkreasikan tujuh kepingankepingan geometeri tangkram tersebut dan menyusunnya sesuai dengan kreativitas anak. Peserta didik menggunakan berbagai mainan tangkram dari berbagai bahan seperti potongan kertas, potongan gabus, potongan triplek, potongan kayu bahkan menggunakan potongan kertas origami.

Melalui berbagai alat permainan edukatif tangkram ini, mendorong para peserta didik di empat lembaga pendidikan anak usia dini tersebut memotifasi anak untuk menyukai matematika geometri, bahkan melalui alat permainan edukatif tangkram ini telah memberikan kesenangan kepada peserta didik kepada alat permainan tangkram, peserta didik dapat mengeluarkan berbagai ide dalam bermain misalnya dengan membuat bentuk Bintang, orang-orangan dan berbagai jenis makhluk hidup maupun benda-benda yang dilingkungan sekitar anak.

Hasil penelitian ini didukung dengan pernyataan Putri Rahmi, dkk di TKN Pembina Lawe Alas, menyatakan bahwa bermain tangram mampu meningkatkan kreativitas peserta didik dalam mengenal bentuk-bentuk geometri. Melalui 3 tahap pengujian yang membuat anak mengalami peningkatan disetiap tahapannya, sehingga secara keseluruhan terjadi perkembangan kreativitas anak mencapai $70 \%$ melalui 
permainan tangram. Menurut peneliti Putri Rahmi tersebut, tingkat keberhasilan dalam bermain tangram ini tidak terlepas dari cara dalam menyampaikan cara bermain dan memotivasi peserta didik agar anak mau mengikuti arahan serta memberikan pujian ketika peserta didik selesai mengerjakan tugasnya membuat peserta didik merasa dihargai dan merasa senang. (Putri Rahmi, dkk, 2020)

Penelitian ini juga menemukan bahwa menciptakan berbagai bentuk dari kepingan-kepingan geometri dapat meningkatkan kreativitas pada anak usia dini. Dalam berbagai analisi penelitian yang dilakukan pada Kelompok B TK IT Permata Bunda Mranggen Demak, Kelompok B di TK Aba Jemawan IV Jatinom dan Kelompok Belajar Bina Insan Mandiri Kecamatan Cimalaka Kabupaten Sumedang yang kesemunya menyatakan bahwa permainan tangkram tersebut memberi pengaruh positif pada peserta didik, terbukti melalui permainan tngkram ini peserta didik menjadi lebih mandiri, menumbuhkan motivasi belajar, menciptakan kerjasama antar peserta didik, menumbuhkan sikap menyukai kegiatan yang berhubungan dengan seni dan kreativitas. Peserta didik lebih kreatif dalam menciptakan bentuk sebuah permainan dan anak mampu menciptakan sebuah keindahan dalam hasil karyanya (Siti Khoirun Nisya, 2012).

Selain itu, dalam kegiatan permianan dengan menggunakan media geometri, kreativitas anak dalam menciptakan bentuk mengalami peningkatan dalam keterperincian (elaboration) yaitu peserta didik mampu menyatakan pengarahan ide/gagasan imajinasi dalam bentuk hasil karya sebuah gambar secara terperinci dan detail, teori keterperincian ini berhubungan dengan persentasi peningkatan kreativitas anak dalam menciptakan bentuk. Hal ini juga didukung oleh persentasi peningkatan kreativitas peserta didik dalam menciptakan bentuk yang dikatagorikan kreatif dengan menggunaan siklus, peningkatan tiap siklus diantaranya semua peserta didik dapat menyelesaikan pekerjaan sendiri sesuai imajinasinya yang mendorong menghasilkan banyak gagasan, yang dituangkan kedalam bentuk hasil karya berupa gambar dari susunan ragam bentuk geometri yang masing-masing berbeda dan unik serta semua peserta didik memiliki rasa bangga dan percaya diri terhadap hasil karyanya sendiri, tidak segan atau malu memperlihatkannya juga menceritakan didepan teman atau orang lain. (Erna Roostin, 2019).

Kemudian penulis juga menemukan manfaat penggunaan tangram adalah untuk membantu peserta didik dapat mencapai standar kurikulum anak usia dini, dimana tangram dapat mendorong keterlibatan kreativitas dari peserta didik dalam pembelajaran, melalui tangkram peserta didik ditantang untuk menggabungkan, membagi, dan mengatur ulang tujuh potongan. Dengan kata lain, penggunaan tangram sebagai media pembelajaran dapat meningkatkan kreativitas peserta didik, dalam hal ini membuktikan pendapat para ahli bahwa tangram memiliki beberapa manfaat bagi anak-anak, diantaranya adalah sebagai berikut. 1) Mengembangkan rasa suka terhadap geometri, 2) Mampu membedakan berbagai bentuk, 3) Mengembangkan perasaan intuitif terhadap bentuk-bentuk dan relasirelasi geometri, 4) Mengembangkan kemampuan rotasi spasial, 5) Mengembangkan kemampuan pemakaian kata-kata yang tepat untuk memanipulasi bentuk (misalnya 'membalik', 'memutar', 'menggeser'), serta 6) Mempelajari apa artinya 'kongruen' (bentuk yang sama dan sebangun). Bohning and Althouse (1997)

Hasil penelitian Bohning \& Althouse (1997, hlm.239) tersebut menyatakan bahwa pengalaman menggunakan tangram dapat membantu peserta didik mengembangkan sikap positif terhadap geometri, mengembangkan keterampilan identifikasi dan klasifikasi mereka, dan menumbuhkan pemahaman tentang konsep dan hubungan geometris dasar. Hal ini didukung juga melalui penelitian yang dilakukan oleh Siew, et al (2013) yang memadukan permainan tangram dengan fase pembelajaran Van Hiele. Van Hiele adalah sebuah teori yang membagi pemahaman peserta didik terhadap geometri melalui lima tahapan, yaitu: (1) visual; (2) analisis; (3) deduksi informal; (4) deduksi, dan (5) akurasi. Pada tahap pertama (visual) peserta didik mengenali bentuk dan angka dengan penampilan global mereka. Misalnya, peserta didik mengenali segitiga, persegi, jajaran genjang dan sebagainya berdasarkan bentuknya, tetapi mereka tidak secara eksplisit mengidentifikasi sifat-sifat dari angka-angka ini. Pada tingkat kedua (analisis), peserta didik mulai menganalisis sifat-sifat bangun datar dan mempelajari cara yang sesuai untuk menggambarkannya. Pada tingkat ketiga (deduksi informal), peserta didik dapat mengidentifikasi hubungan antar bangun datar (misalnya, persegi dianggap persegi panjang karena memiliki semua sifat persegi panjang). Tingkat keempat adalah deduksi, yaitu membuat kesimpulan dan tingkat kelima adalah akurasi, yaitu peserta didik menyadari pentingnya ketetapan prinsip yang mendasari suatu pembuktian. Penelitian ini menunjukkan bahwa fase pembelajaran Van Hiele dengan menggunakan Tangram dapat diterapkan dalam matematika anak usia dini dan terbukti dapat membantu peserta didik mencapai 
tingkat pemikiran geometris yang lebih baik. Dengan demikian, permainan tangram dapat meningkatkan pemahaman tentang konsep geometris pada peserta didik. Siew, et al (2013)

Sedangkan Russell dan Bologna (2014, hlm. 34) menyatakan bahwa tangram merupakan media sederhana namun menarik bagi peserta didik, tidak hanya dapat memperkenalkan konsep-konsep geometris, tetapi juga sebagai alat peraga yang sangat baik bagi peserta didik dan guru untuk terlibat dalam tugas-tugas yang mendorong visualisasi spasial, dimana visualisasi ini diperlukan oleh peserta didik dalam mempelajari geometri, seperti yang dinyatakan oleh Costa "For elementary learners, they first grasp the idea of geometric shapes by visualization". Siew et al (2013, hlm. 101).

\section{SIMPULAN}

Perkembangan kreativitas anak usia dini dapat dikembangkan melalui permainan bentuk geometri seperti tangram dan kepingan geometri di era digital. Permainan tersebut memberikan kesempatan anak untuk menyusun bentuk-bentuk geometri ke dalam bentuk lain sesuai dengan kreativitas anak tersebut. Tingkat keberhasilan dalam bermain tidak terlepas dari strategi dalam menyampaikan cara bermain dan memotivasi anak serta memberikan pujian ketika anak selesai mengerjakan tugasnya sehingga anak merasa dihargai dan merasa senang. Adapun dalam kegiatan penggunaan media geometri, kreativitas anak dalam menciptakan bentuk mengalami peningkatan dalam keterperincian (elaboration) yaitu anak mampu menyatakan pengarahan ide/gagasan imajinasi dalam bentuk hasil karya sebuah gambar secara terperinci dan detail, teori keterperincian ini berhubungan dengan persentasi peningkatan kreativitas anak dalam menciptakan bentuk.

\section{UCAPAN TERIMA KASIH}

Penulis mengucapkan terima kasih kepada semua pihak yang telah membantu penelitian ini, sehingga dapat dipublikasikan.

\section{DAFTAR PUSTAKA}

Kustiani, R. (2019). Meningkatkan Kreativitas Anak Melalui Bermain dan Berkarya dari Bentuk Geometri Kelompok B di RA Nurussibyan Randu Garut Tugu Semarang Tahun Ajaran 2017/2018 (Skripsi Sarjana). Universitas Islam Negeri Walisongo. Retrieved November 5, 2020, from http://eprints.walisongo.ac.id/9798/

Roostin, E. (2019). Penggunaan Media Geometri untuk Meningkatkan Kreativitas Anak dalam Menciptakan Bentuk. Journal on Early Childhood, 2(1), 1-8. Retrieved November 5, 2020, doi: https://doi.org/10.31004/aulad.v2i1.10

Nisya, S. K. (2012). Peningkatan Kreativitas Anak Melalui Permainan Kepingan Geometri pada Anak Kelompok B Di Tk Aba Jemawan IV Jatinom Tahun Pelajaran 2012/2013 (Skripsi Sarjana). Universitas Muhammadiyah Surakarta. Retrieved November 5, 2020, from http://eprints.ums.ac.id/id/eprint/21358

Nursanti, I., \& Khasanah, I. (2015). Upaya Meningkatkan Kreativitas Anak Melalui Bermain Mencipta Bidang dari Kepingan Geometri pada Kelompok B TK IT Permata Bunda Mranggen Demak Tahun Ajaran 2014/2015. Jurnal Penelitian Dalam Bidang Pendidikan Anak Usia Dini, 4(2), 141-152. Doi:https://doi.org/10.26877/paudia.v4i2 Oktober.821

Rahmi, P., M., Fajriah, H., \& M. (2020). Penerapan Alat Permainan Edukatif Tangram untuk meningkatkan Kreativitas Anak dalam Mengenal Bentuk Geometri di TKN Pembina Lawe Alas. Jurnal Raudhah, 8(1), 81-91. Http://dx.doi.org/10.30829/raudhah.v8i1.588

Handayani, P. H., Gandamana, A., \& F. (2017). Pengembangan Kreativitas Anak Usia Dini dalam Keluarga. Jurnal Keluarga Sehat Sejahtera, 15(2), 46-55. Retrieved November 12, 2020, from http://eprints.ums.ac.id/id/eprint/21358

V.Wiratna Sujarweni,Metodeologi Penelitian ( Yogyakarta : Pustaka Baru Perss, 2014),h.57

Sukardi,Metodologi Penelitian Pendidikan Kompetensi dan Praktiknya (Jakarata : PT Bumi Aksara,2013), h.33.

Pitadjeng. (2006). Pembelajaran Matematika yang Menyenangkan. Jakarta: Depdiknas

Mufti, N. N., Pranata, O. H., \& Muharram, M. R. (n.d.). Studi Literatur: Tangram Sebagai Media Pembelajaran Geometri. Jurnal Kajian Pendidikan Dasar, 5(2), 93-99. Doi:https://doi.org/10.26618/jkpd.v5i2.3566 